\title{
Managing Technology Transfer in Open Innovation: The case Study in Taiwan
}

\author{
Tao Huang \\ Industry Technology Research Institute, Technology Transfer Center, Taiwan \\ Rm. 125, Bldg. 52, 195, Sec. 4, Chung Hsing Rd., Chutung, Hsinchu, Taiwan 31040, R.O.C.
}

Tel: 886-3-5912714Ｅ-mail: taohuang@itri.org.tw

Wen-Cheng Wang

Department of Business Management, Hwa Hsia Institute of Technology, Taiwan

111 Gong Jhuan Rd., Chung Ho, Taipei, Taiwan, R.O.C

Tel: 886-2-89415022 E-mail:wcwang@cc.hwh.edu.tw

Yun Ken

Business Administration, National Yunlin University of Science \& Technology Yunlin, Taiwan

123 University Road, Section 3, ouliou, Yunlin 64002, Taiwan, R.O.C.

Tel: 886-5-5342601 ext. 5241 e-mail: yunken@yuntech.edu.tw

Chun-Yao Tseng

Department of Business Administration, Tunghai University, Taiwan

181, Section 3, Taichung Port Road, Taichung City 40704, Taiwan, R.O.C.

Tel: 886-4- 2359-0121 ext. 35109 e-mail: cytseng@thu.edu.tw

\section{Chi-Lin Lee}

Business Administration, National Yunlin University of Science \& Technology Yunlin, Taiwan

123 University Road, Section 3, ouliou, Yunlin 64002, Taiwan, R.O.C.

Tel: 886- 9-2296-8320Ｅ-mail: g9522726@yuntech.edu.tw

\begin{abstract}
Universities, especially for technology transfer activities, always play the role of intermediaries in the innovation process. This study investigates three main issues related to open innovation based on bureaucratic perspective and scientific perspective. First, the protection power of technology is evaluated. Secondly, this study demonstrates determinants of successful technology transfer. Finally, this study examines the efficacy of technology transfer office in open innovation. Basing on literature reviews, we take the case study in Taiwan and try to make further insights for managing technology transfer in open innovation.
\end{abstract}

Keywords: Technology transfer, Open innovation, Taiwan

\section{Introduction}

Open innovation has been defined as a paradigm that assumes that firms can and should use external ideas, and internal and external paths to market, as the firms look to advance their technology (Chesbrough, 2003). In the past, closed business model could bring great market revenues, and it usually exceeded internal development cost. Because of the shorter product life and rising costs of innovation, it is getting harder to cover development cost in current business environment. Concerning open business model, it enables an organization to be more effective in creating as well as capturing value-added. They help create value by leveraging many more ideas from a variety of external concepts. They also allow greater value capture by utilizing a firm's key asset, resource or position not only in that organization's own operations but also in other companies' businesses. 
Compare with closed business model, open business model attacks the cost side of the problem by leveraging external research-and-development resources to save time and money in the innovation process. Open business model also attacks the revenues side; it participates in other segments through licensing fees, joint ventures and spin-offs, among other means. These different streams of income create more overall revenue from the innovation. The result is that innovation becomes economically attractive again, even in a world of shorter product life cycles (Chesbrough, 2007).

There are many well recited stories of open innovation such as open source code of Sun Microsystems, licensing operation and open source code of IBM, open exploratory research of Intel, global innovation network of Procter and Gamble (http://www.ginnn.com/index.aspx), joint venture and R\&D of Philips, merges and acquisitions of Cisco, licensing operation of DuPont. All of them have shrunk their internal R\&D inputs and successfully tapped into external sources of innovation, that have helped to catapult growing worldwide interest in this apparent new paradigm.

Analysis of the innovation becoming more open over time (Coombs, Harvey, \& Tether, 2003), in turn associated with increasing levels of collaboration and outsourcing (Chatterjee, 1996; J. Howells, 1999), has led the analysis to investigate more closely the role of the nodes and links in innovation process. According to Howells (2006) who used the term of 'intermediaries' which means the roles who perform a variety of tasks within the innovation process. Universities, especially for technology transfer activities, always play the role of intermediaries in the innovation process. Tornatzky (2000) argued universities play vital positions in technology transfer process, they perform the bridges (Bessant \& Rush, 1995; McEvily \& Zaheer, 1999), brokers (Hargadon, 1998), third parties (Mantel \& Rosegger, 1987), intermediary firms (Stankiewicz, 1995), information exchange (Popp, 2000) and superstructure organizations (Lynn, Reddy, \& Aram, 1996). Universities technology transfer activities (i.e. university science parks; USPs) usually involve idea generation, patenting and development within the technology, funding, commercial and team sectors. The activities are complex, interrelated and interdependent, and are characterized by being high risk and extremely dynamic in comparison to other types of small firm formation and development (McAdam, Galbraith, McAdam, \& Humphreys, 2006).

Therefore, this study wants to explore technology transfer practice in Taiwan and investigates three main issues related to open innovation based on bureaucratic perspective and scientific perspective (see figure 1). First, the protection power of technology is evaluated. Secondly, this study demonstrates determinants of successful technology transfer. Finally, this study examines the efficacy of technology transfer office in open innovation.

The paper begins with a review of the relevant open innovation and technology transfer literatures in order to dig up the research problem and develop investigative purpose. The paper will then describe determinants of technology transfer. The third section introduces methodology and the cases. The fourth section describes the role of intellectual property rights in bringing inventions to practice. The fifth section discusses the role of universities technology transfer offices in bringing inventions to practice, and in the final section, we make conclusions and implications.

\section{Determinants of technology transfer}

According to the investigation of Rahal and Rabelo (2006) which identified the determinants and decision factors that influence or impact the licensing and commercialization of university technologies. We integrate Rahal and Rabelo (2006) results and classifies technology transfer determinants as six major types: institutional determinants, inventor-related determinants, technology-related determinants, market and commercialization-related determinants and intellectual property-related determinants.

The first type of technology transfer determinants is "institutional determinants". They are classified as technology transfer office (TTO) determinants (Hauksson, 1998), universities licensing policies determinants (Hsu \& Bernstein, 1997) and institutional prestige influence determinants (Sine, Shane, \& Gregorio, 2003). In the aspect of TTO determinants, Tornatzky (2000) argued appropriate staffing, clearly articulated mission, customer-friendly orientation, clear policies and procedures, supportive university culture are vital for TTO practice. Concerning the policies determinants, the Bayh-Dole Act encouraged universities in United States to develop "technology transfer offices" to market and manage their patentable inventions (Colyvas, et al., 2002). As for the institutional prestige determinants, Sine et al. (2003) found prestigious universities may be better able than less prestigious universities to licence their inventions not because the technology production is better, but because the universities that produce them are perceived as more prestigious.

The second type of technology transfer determinants is "inventor-related determinants". They are classified as inventor involvement and cooperation as a team player (Jensen \& Thursby, 2001; Thursby \& Thursby, 2002), inventor being recognised as a technology leader (Allen, 1977; D. Berry, C. \& Broadbent, 1987; D. C. Berry \& 
Broadbent, 1984), inventor credibility in the field (Allen, 1977; D. Berry, C. \& Broadbent, 1987; D. C. Berry \& Broadbent, 1984), inventor has realistic expectations about his or her technology (Galbraith, 1990), incentives to inventor by the licensor (Jensen \& Thursby, 2001). The first step of formal technology transfer is "legally disclosing" which involves inventor filing an invention disclosure with his or her TTO. In this filing, the invention is described, evidence for the date of the invention is provided, the funding source is identified, and the inventors are named (Tornatzky, 2000).

The third type of technology transfer determinants is "technology-related determinants". The most important determinants are technology nature and sophistication, technology's significant benefits and advantages as identified and perceived by the user, technology's quantifiable benefits and advantages as perceived by the user when compared to current competing products, technology's sustainable competitive advantages and superiority as perceived by the user, the availability of a functioning prototype, the technology's degree of compatibility to other necessary technologies (Rogers, 1995), technology scope or future uses, technology uniqueness and superiority, the barriers to entry, the newness and the non-obviousness in the technology (Nerkar \& Shane, 2007), the technology's degree of dependability on other necessary technologies, the technology's identifiable and quantifiable technological risks and weaknesses, the technology development time to market, the stage of development of technology, the technical feasibility (such as technical problems are solvable) (Rahal \& Rabelo, 2006).

The fourth type of technology transfer determinants is "commercialization-related determinants". Based on literature review of (Rahal \& Rabelo, 2006), they classified the determinants as follows: the technology's identifiable current and immediate market needs, the absence of a dominant competitor in the technological field, the technology has a large definable potential market, the technology's market growth anticipation, the technology's expected market trend the time for the technology to reach the target market penetration, market accessibility for the technology (no dominant technology), the technology's competitive pricing, the technology has a reasonable probability of market success, the technology being first to market (early mover advantage), the R\&D necessary for the technology to reach the product development stage, the technology's expected payoff period, the technology's expected positive return on investment within a specified period, the technology's financial risk.

The fifth type of technology transfer determinants is "intellectual property-related determinants". They are classified as the complete and clean technology's literature search, the completed patent search, and the patent search is clear and clean, the confidentiality of the technology (no oral or written disclosures), the technology has no prior claims, the strength of intellectual property, exclusivity of intellectual property (Rahal \& Rabelo, 2006).

Finally, we integrate another type of technology transfer determinants which named "others". They contain organizational psychological factors and universities-industries technology transfer experiences which are classified as the trust and support of chief or leader in universities, the important role of university in the regional economic development, the unique function of integrating technology transfer into research, university's resources which are offered to technology transfer activities, the TTO needs to consider technology licensing and derivative new ventures, to offer professional knowledge or educate for TTO employees, to evaluate the potential market needs of technology, the management of research revenues, the connections between university and enterprise, the quality of college, the scale of TTO, the age of TTO, the ownership of academic intellectual property rights, the channel of technology transfer, the independence of university, external competitive environment (Friedman \& Silberman, 2003; Smilor \& Matthews, 2004). The determinants of technology transfer are shown in table 1.

\section{Methodology and a survey of the cases}

\subsection{Research framework}

Our investigation is an exploratory research; we integrate literatures of university-industry technology transfer and proposed a conceptual framework in order to be taken as the research foundation of survey data. The aims of this research does not focus on constructing or proofing a theoretical model, oppositely, getting technology transfer practical insights through case studying and secondary data analyzing are the primary purposes. Our research takes technology transfer literatures as the basic of research framework. With that, we try to realise university-industry technology transfer mechanisms or managerial modes, promotional strategies of domestic TTOs. Simultaneously, this study takes the samples of well-performed domestic TTOs and the superior technology transfer cases awarded by national science council. Basing on the descriptions above, drawing technology transfer practice in open innovation and exploring the role of universities intellectual property rights and TTOs in bringing inventions to practice in Taiwan are the main tasks in this research. 


\subsection{The sample}

In sample selection, we have considered the effects of technology fields, geographical distribution and university attribute (i.e. national or private schools). Regarding interview personnel, referred McAdam et al. (2006), we choose the main stakeholders who have abundant practical experience about technology transfer in universities which conclude university inventors (scientific perspective) and the administrators of TTOs (bureaucratic perspective). We integrate each perspective referring the role of technology protection mechanisms and position of TTOs and derive research conclusions.

This research tries to take different perspectives (scientific and bureaucratic perspective) to understand or explore the following questions: the protection power of intellectual property rights for technology, what are the important technology transfer determinants, and understand the role of university TTOs in technology transfer process.

Our investigation focuses on exploring the importance of patented technology in protection power and technology transfer for TTO and inventor. To prevent cognitive differences between interviewer and interviewee, questionnaires are sent to TTO and inventor in advance, and the details of questionnaire will be further discussed before interview.

Concerning interview method, this study adopts face to face interview to prevent interviewees' questions from questionnaire. During every interview, the interviewer will try to build a cognitive base toward each concept, and prompts and guides the interviewees to express their opinion and to illustrate actual situation.

This study needs to take the perspective of both inventors and TTOs of the Executive Yuan's National Science Council of academic information to get contact with the inventor and TTO which contacts the inventor or the inventor holds in. There are three reasons for this sample selections: (1) technology transfer case which is awarded by state organs; (2) inventor of the sample holds leading position in his field, and has won prize of national academic or technology transfer case; (3) TTO of the sample holds the leading position in technology transfer case of domestic university and authorised amount. The basis and process of sampling is illustrated as follows.

\subsection{Technology transfer offices}

Selection principles: (1) geographical area - hope the samples evenly distributes around north, central and southern areas; (2) university segment, including national, private and science \& technology university; (3) technology segment - covering machinery and electronics, chemical materials, and biotechnology three technical fields. Based on above selection principles, this study chooses each two universities from northern, central and southern universities, and respectively using A, B, C, D, E, and F for the code that indicates each university TTOs.

\subsection{Inventors}

Based on 2007 won the National Science Council of Taiwan, Professor of Technology Transfer Award for Encouragement of Cases in which qualified professors: Taiwan University of five professors; Tsing-hua University of two professors; Transportation University of five professors; National Cheng Kung University of two professors; Chung Hsing University of five professors; National Chung Cheng University of one professor; Feng Chia University of one professor; Chang Gung University of one professor; Tamkang University of two professors; Kaohsiung Medical University of one professor; Taipei University of Technology of one professor; Taiwan University of Science and Technology of one professor. Because of time constraints and the inventor's willingness, the study finally interviews five professor, they are $\mathrm{a}, \mathrm{b}, \mathrm{c}, \mathrm{d}$, and $\mathrm{f}$ professors.

After developing concept framework, this study will design interview questionnaire based on the framework and foreign literature. By doing questionnaire interview, we deeply analyze and understand professor's technology invention which whether possesses patent for protect the effectiveness of its technology invention. Moreover, we will study whether the actual process of influence between industry and school, and then further explore the views of inventors about the TTO. Our interview questions divide into TTO and the inventor these two forms of the questionnaire.

This study will combine the literature review and secondary data to collect following questions which can be summed up three categories.

1) The protection power of intellectual property: Rahal and Rabelo (2006), Tornatzky (2000) proposed technology to protect the effectiveness of the university there are many important factors, such as patents, business secrets, technology lead time, product manufacturing, etc. In technology transfer licensing, there are 
also many important reasons, such as intellectual property rights, potential market demand, technology feasibility, commercialization time. This study consults the literature as the scale of the questionnaire.

2) Technology type for technology transfer: Tornatzky (2000) proposed that universities played a very crucial role in technology transfer, both in the searching and signing contracts with firms, even follow-up involved in the degree of high or low. It would also affect the future technology trends. Mostly universities transfer technologies which belong to early stage (embryonic) and commercialization ones (Colyvas, et al., 2002). Besides, the most important thing for technology transfer is the way to charge royalty and derivative of charge mode (Atuahene-Gima \& Patterson, 1992).

3) The cooptation between TTO and the inventor: the TTO often plays a key role in technology transfer process (Tornatzky, 2000). TTOs have closed relationships with inventors, they perform the bridges (Bessant \& Rush, 1995; McEvily \& Zaheer, 1999), brokers (Hargadon, 1998), third parties (Mantel \& Rosegger, 1987), intermediary firms (Stankiewicz, 1995), information exchange (Popp, 2000) and superstructure organizations (Lynn, et al., 1996) for inventors.

The summary of the cases are shown in table 2 and table 3 .

\section{The role of intellectual property rights in bringing inventions to practice}

\subsection{The protection power for technology}

In the perspective of technology protection, patent has great effectiveness. Three of the five inventors (b, c, d) and most TTO administrators (A, B, D, E) thought patent will offer higher protection power for technology and research outcomes than any other technology protection mechanisms. In TTO's opinions, valid patent can offer exclusivity, especially in the legal aspect, and hence has great protection effect for inventions. Meanwhile, administrator D thought patent is especially crucial while inventions are commercialised technology. If there is no valid patent, then it might be risking the possibility of infringement, thus increasing business risk.

Regarding other technology protection mechanisms, two inventors $(a, b)$ and two TTO administrators (E, F) agree that in certain situations, the protection effectiveness of secrets (or know-how) would be superior to the efficacy of other intellectual property rights. Inventor a thought in the industry of technology superiority or process complex, secrets or know-how will provide better protective effect. However, for short life-cycle technology or industry, patent application process is relatively time-consuming and therefore leader time of technology is a better strategy for technology protection. Besides, administrator $F$ thinks that in the biotechnology field, the importance of secret will exceed patent. Further on, this TTO administrator considers that once a company owns the pivotal technique and establish entry barriers, then competitors will be difficult to enter because of the established brand recognition. Thus, for the perspective of administrator F, early mover advantage is crucial for technology protection, especially for biotechnology field.

To recap, in our case studies patent is crucial in technology protection, especially for commercialised technology. Secret and know-how are useful mechanisms, especially for technology superiority or process complex industry. Leader time is an important means for short life-cycle technology. For specific industrial, early mover advantage of technology will impact the protection power, and this is corresponding to Rahal and Rabelo (2006). Accordingly, in the perspective of technology protection power, there is no optimal choice. The best technology protection strategy is depended on situational factors, e.g. technology fields, industrial attributes, and this is also similar with the claims Colyvas et al. (2002). The summary of technology protection mechanisms are shown as table 4.

\subsection{The important technology transfer determinants}

The results of technology transfer determinants are integrated in table 5. Three inventors (a, b, d) and three TTO administrators (B, D, E) suggest that patent has essential influence for the realization of successful technology transfer. They think techniques with patents protection is the preliminary element for successful technology transfer. In other words, one inventor has to possess the valid and clean patent right, and then foreign firms have the willingness to negotiate with you. This finding coincides with the investigations of Rahal and Rabelo (2006). Tornatzky (2000), Rahal and Rabelo (2006) also claimed the authorization of intellectual property is the fundamental of technology transfer; besides, technological know-how, clear patent, strength of intellectual property and the confidentiality of the technology are also influential for a successful technology transfer.

However, possessing a technique with patent is not the assurance for technology transfer, inventor involvement and technology's identifiable current and potential market needs are the key points. Four inventors (a, b, c, f) and two TTO administrators (B, F) agree the importance of inventor involvement, they also argue university-industry cooperation is a good mechanism for technology transfer. Similar with the assertions of Thursby and Thursby 
(2003), integration between inventors' techniques and industries' financing is beneficial for technological development, but inventor involvement and cooperation is the significant determinant. Besides, administrators A and $\mathrm{C}$ don't see patent as the crucial determinant for technology transfer, they both emphasise current market needs of technology is the key. Administrator E argues that patent is vital in the industry-industry technology transfer and less important in the university-industry technology transfer. And the potential benefit or market needs of the technology is the determinant of successful technology transfer.

Moreover, based on the investigations of Mowery et al. (2001) which indicated the prestige of inventors or universities is also a crucial determinant for successful technology transfer. In our case studies, we get the contrary results: from the perspectives of inventors or TTO administrators, the factor of institution prestige is not beneficial for technology transfer. For the inventors who just begin to research, they might contact firms easily by means of the reputations of their own universities or the performance of TTO, but it is not easy for further development. As for the experienced inventors, the core of technology transfer is commercial value of inventions, not the prestige. If there is an invention with no potential market needs, it is uneasy to realise technology transfer. Furthermore, the possible reasons for the different phenomena on the effect of prestige are the immature technology transfer environment and the lower technology transfer performance or efficiency; hence the reputations of domestic schools have no significant influence on the realization of technology transfer. The important technology transfer determinants are shown in table 5.

\section{The role of universities technology transfer offices in bringing inventions to practice}

Different form survey results of Colyvas et al. (2002) which argurd TTOs' marketing activities are weak, in our case studies, most of the inventors (a, b, c, f) identify the efficacy of TTOs. But there is one inventor (d) who doubts the effectiveness of TTOs. Here we integrate the positive and negative viewpoints for TTOs:

\subsection{The positive viewpoints about TTOs}

Inventor $\mathrm{a}$ and $\mathrm{b}$ both think TTOs enable them to focus on the research and invention activities. They deal with many technology licensing activities, e.g. patent applications, firms search and bridge, help to make contract with firms and negotiate licensing fee. Base on the reasons above, these two inventors recognise the role of TTOs in bringing inventions to practice.

Inventor $\mathrm{c}$ is a retired employee in a famous American enterprise, what he wants to do is contribute social welfare by offering his own inventions. Thereupon, the TTO provides a set of services including the confirmation of royalty, derivative licence incomes and contract relative affairs. He trusts his university TTO very much and he says "the only one thing he has to do is t sign his name on the contract". To sum up, he feels TTO is well-performing and beneficial for bringing inventions to practice.

Inventor $\mathrm{f}$ learned a lot of precious technology transfer knowledge from TTO, inclusive of the contract, technology transfer data delivery and educational training. In the beginning, inventor $\mathrm{f}$ focuses on embryonic inventions and with no conversance about technology transfer practice. After the assistance of TTO administrators, inventor $\mathrm{f}$ transforms his researches into applied technologies. Following, the TTO encourages and offers resources to promote his inventions and finally make a match with firms. Now, this inventor is familiar with the mechanism of university-industry cooperation and TTO plays a crucial position. In additional, inventor $\mathrm{f}$ considers after technology licensing, there will be numerous dissensions and a well-functioned TTO can solve the troubles for inventors. Therefore, corresponding with the findings of Bessant and Rush (1995), McEvily and Zaheer (1999) and Mantel and Rosegger (1987), inventor f claimes that the TTO essentially performs the bridges, especially in contract making, intellectual property protecting and being the third parties between inventors and industry.

\subsection{The negative viewpoints about TTO}

From legal perspective, inventors d don't believe that university TTOs can offer virtual assistance in bringing universities inventions to practice. Inventor $d$ thinks university TTOs, especially in Taiwan, can not prevent university inventions from being infringed. The administrators of TTOs lack of the experience and knowledge about patent infringements and patent litigations. For this phenomenon, inventor d proposes two possible reasons: first, the shortage of licensing staffs and hence can't fight against the violators. Second, considering prestige and hence universities in Taiwan are in fear of litigations. If schools don't take active legal actions, it would get hard to perform further technology transfer activities. Since universities inventions (i.e. licensors) are infringed and do not fight back availably, then the licencees will be suffered from great commercial loss. In addition, inventor $\mathrm{d}$ finds the secrets protection system is not perfect in Taiwan. There are many technology stealing or leakage events occurring in university laboratories through the lab members or students. Regarding technology 
protection, university TTOs have no ability to conquer this problem, and hence change inventors' researches from applied or commercial inventions to embryonic inventions. As inventor d says-"this is a bad news for university technology transfer". Therefore, inventor d argues patent maintenance is more important than patent application. If universities can not secure inventors' technological outcomes, then it will decrease inventors' willingness for further technology transfer.

In the angle of TTO administrators, they recognise TTO's contributions and listed their principal tasks which include dealing with administrative affairs, searching for the proper technology transfer firms, patent application and patent claims analysis, being contract consultants, the determination of royalty and derived licence income.

In our survey, we understand TTO in Taiwan is usually affiliated to the office of research and development or incubation center of university; there is no independent department for TTO, and the chief of the TTO is a concurrently position which is usually held by university teacher. The main task of TTO chief is to sign the contracts; the practical technology transfer activities are performed by external technology transfer managers, or directed by TTO full-time staffs. In additional to technology transfer business, these staffs have other heavy loadings of administration affairs and patent applications service. To sum up, the specialization of TTOs in Taiwan is not mature enough and this may cause role ambiguity for TTO members. Nowadays, technology transfer in Taiwan has to dependent on TTO's assistance, and most of the TTO administrators still approve TTO's contribution for technology transfer. The results of the attitude toward the efficacy of TTO are shown in table 6 .

\section{Conclusion and implications}

University licensing has increased dramatically since passage of the Bayh-Dole Act in 1980, giving universities the right to retain title to and licence inventions resulting from federally sponsored research. U.S. government typically assigns patents and other forms of property rights to innovators to give private agents incentives to engage in costly research activities. Besides, there has an equally dramatic increase in the number of universities with TTOs that manage the patenting and licensing of university inventions (Colyvas, et al., 2002). Extending the spirit of the Bayh-Dole Act in the U.S., Taiwan declared and executed the Basic Law of Science and Technology in 1999 that encourages university faculties to engage in research activity and patent application. Accordingly, more and more universities set up TTOs to market university inventions and intend to bring university inventions into practice. The aim of this paper is to understand the open innovation by observing technology transfer activities in universities. We take both scientific and bureaucratic perspectives to discuss the technology protection mechanism, technology transfer determinants and the role of TTOs in Taiwan.

This paper in our cases suggests that in the open innovation process of universities, we should take different technology protection mechanisms basing on various industrial or technological characteristics. For most respondents, patent is able to offer higher protection power, especially for commercialised technology. Secret and know-how are helpful in technology superiority or process complex industry. Leader time of technology is an important means for short life-cycle technology. And early mover advantage is a good strategy for biotechnology field.

Another finding of this paper is that in the cases we examined, for both scientific and bureaucratic perspectives, patent and inventor involvement are crucial determinants for facilitating technology transfer. Corresponding with the survey of Rahal and Rabelo (2006) which showed the most important technology licencing determinants is the strength of intellectual property, in our survey, a clear and clean patent is considered as the essential element for technology transfer. Regarding inventor involvement, Thursby and Thursby (2002) identified personal contact or involvement between university inventors and industry as the most important source of technology transfer and commercialisation success. Similar results are found in our survey which indicates university-industry cooperation mechanism is important for the successful technology transfer. University is a good source of technology, and firms may exploit open innovation from university by means of the close cooperation with inventors. Besides, different from scientific perspective, bureaucratic perspective emphasises the importance of market factor. They argue current and potential market needs are the determinants for successful technology transfer. The possible reason for the conceptual gap is the distance from the market. TTO employees are usually near the market-end and hence sensible of the importance of market needs.

Finally, concerning the role of TTOs in bringing inventions to practice, different from Colyvas (2002) who denied the contributions of TTOs in marketing university inventions, our paper recognises the efficacy of TTOs and approves TTOs' contribution for technology transfer. But there is one inventor argued the legal environment of intellectual property in Taiwan is not mature and health enough, university TTOs can not prevent inventions form being infringed. And hence it is not easy for universities to bring inventions to practice. This may stop 
university inventors transferring their inventions to industry application and weaken the effect of technology transfer policy.

\section{References}

Allen, T. J. (1977). Managing the Flow of Technology: Technology Transfer and the Dissemination of Technology Information Within the R\&D Organization: MIT Press.

Atuahene-Gima, K., \& Patterson, P. (1992). The Impact of Managerial Attitudes on Technology Licensing Performance. European Journal of Marketing 26( 3), 52-63.

Berry, D., C., \& Broadbent, D. E. (1987). The Combination of Explicit and Implicit Learning Processes in Task Control. Psychological Research, 49(1), 7-15.

Berry, D. C., \& Broadbent, D. E. (1984). On the Relationship Between Task Performance and Associated Verbalizable Knowledge. The Quarterly Journal of Experimental Psychology, 36A, 209-231.

Bessant, J., \& Rush, H. (1995). Building Bridges for Innovation: The Role of Consultants in Technology Transfer. Research Policy 24(1), 97-114.

Chatterjee, D. (1996). Accessing External Sources of Technology. Research Technology Management 39 (2), $48-56$.

Chesbrough, H. W. (2003). Open Innovation: The New Imperative for Creating and Profiting from Technology. Boston, MA.

Chesbrough, H. W. (2007). Why Companies Should Have Open Business Models. MIT Sloan Management Review, 48(2), 22-28.

Colyvas, J., Crow, M., Gelijns, A., Mazzoleni, R., Nelson, R. R., Rosenberg, N., et al. (2002). How Do University Inventions Get Into Practice? Management Science 48(1), 61-72.

Coombs, R., Harvey, M., \& Tether, B. S. (2003). Analysing Distributed Processes of Provision and Innovation. Industrial and Corporate Change, 12(6), 1125-1155.

Friedman, J., \& Silberman, J. (2003). University Technology Transfer: Do Incentive,Management and Location Matter? Journal of Technology Transfer 28(1), 17-30.

Galbraith, C. S. (1990). Transferring Core Manufacturing Technologies in High-Technology Firms. California Management Review, 32(4), 56-70.

Hargadon, A. (1998). Firms as Knowledge Brokers: Lessons in Pursuing Continuous Innovation. California Management Review 40(3), 209-227.

Hauksson, A. G. (1998). The Commercialization of University Research Discoveries: Are University Technology Transfer Offices Stimulating the Process? . Massachusetts.

Howells, J. (1999). Research and Technology Outsourcing. Technology Analysis \& Strategic Management 11(1), 17-29.

Howells, J. (2006). Intermediation and the Role of Intermediaries in Innovation. Research Policy, 35 (5), 715-728.

Hsu, D. H., \& Bernstein, T. (1997). Managing the University Technology Licensing Process: Findings from Case Studies. Association of University Technology Managers 9, 1-33.

Jensen, R., \& Thursby, M. (2001). Proofs and Prototypes for Sale: The Licensing of University Inventions. American Economic Review 91(1), 240-259.

Lynn, L. H., Reddy, N. M., \& Aram, J. D. (1996). Linking Technology and Institutions: The Innovation Community Framework. Research Policy, 25(1), 91-106.

Mantel, S. J., \& Rosegger, G. (1987). The Role of Third-Parties in the Diffusion of Innovations: A Survey. In R. Rothwell, Bessant, J. (Eds.) (Ed.), Innovation: Adaptation and Growth (pp. 123-134). Amsterdam: Elsevier.

McAdam, M., Galbraith, B., McAdam, R., \& Humphreys, P. (2006). Business Processes and Networks in University Incubators: A Review and Research Agendas. Technology Analysis and Strategic Management, $18(5$ ), 451-472.

McEvily, B., \& Zaheer, A. (1999). Bridging Ties: A Source of Firm Heterogeneity in Competitive Capabilities. Strategic Management Journal, 20(12), 1133-1156. 
Mowery, D. C., Nelson, R. R., Sampat, B. N., \& Ziedonis, A. A. (2001). The Growth of Patenting and Licensing by U.S. Universities: An Assessment of the Effect of the Bayh-Dole Act of 1980. Research Policy, 30(1), 99-119.

Nerkar, A., \& Shane, S. (2007). Determinants of Invention Commercialization: An Empirical Examination of Academically Sourced Inventions. Strategic Management Journal, 28(11), 1155-1166.

Popp, A. (2000). "Swamped in Information but Starved of Data": Information and Intermediaries in Clothing Supply Chains. Supply Chain Management 5(3), 151-161.

Rahal, A. D., \& Rabelo, L. C. ( 2006). Assessment Framework for the Evaluation and Prioritization of University Inventions for Licensing and Commercialization. Engineering Management Journal, 18(4), 28-36.

Rogers, E. M. (1995). Diffusion of Innovations (4 The Free Press ed.).

Sine, W. D., Shane, S., \& Gregorio, D. D. (2003). The Halo Effect and Technology Licensing: The Influence of Institutional Prestige on the Licensing of University Inventions. Management Science, 49(4), 478-496.

Smilor, R., \& Matthews, J. (2004). University Venturing: Technology Transfer and Commercialisation in Higher Education. International Journal of Technology Transfer and Commercialisation 3(1), 111-128.

Stankiewicz, R. (1995). The Role of the Science and Technology Infrastructure in the Development and Diffusion of Industrial Automation in Sweden. In B. E. Carlsson (Ed.), Technological Systems and Economic Performance: The Case of Factory Automation (pp. 165-210). Dordrecht: Kluwer.

Thursby, J. G., \& Thursby, M. C. (2002). Who Is Selling Selling the Ivory Tower? Sources of Growth in University Licensing. Management Science 48(1), 90-104.

Thursby, J. G., \& Thursby, M. C. (2003). Industry/University Licensing: Characteristics, Concerns and Issues from the Perspective of the Buyer. Journal of Technology Transfer, 28(3-4), 207-213.

Tornatzky, L. G. (2000). Building State Economics by Promoting University-Industry Technology Transfer: National Governors Association. 
Table 1. Determinants of technology transfer

\begin{tabular}{|c|c|}
\hline $\begin{array}{l}\text { Determinants of } \\
\text { technology } \\
\text { transfer }\end{array}$ & Descriptions \\
\hline $\begin{array}{l}\text { Institutional } \\
\text { determinants }\end{array}$ & $\begin{array}{l}\text { 1.Technology transfer office determinants; } \\
\text { 2.Universities licensing policies determinants; } \\
\text { 3.Institutional prestige influence determinants. }\end{array}$ \\
\hline $\begin{array}{l}\text { Inventor-related } \\
\text { determinants }\end{array}$ & $\begin{array}{l}\text { 1.Inventor involvement and cooperation as a team player; } \\
\text { 2.Inventor being recognised as a technology leader; } \\
\text { 3.Inventor credibility in the field; } \\
\text { 4.Inventor has realistic expectations about his or her technology; Incentives to inventor by the } \\
\text { licensor. }\end{array}$ \\
\hline $\begin{array}{l}\text { Technology-relat } \\
\text { ed determinants }\end{array}$ & $\begin{array}{l}\text { 1.Technology nature and sophistication; } \\
\text { 2.Technology's significant benefits and advantages as identified and perceived by the user; } \\
\text { 3.Technology's quantifiable benefits and advantages as perceived by the user when compared to } \\
\text { current competing products; } \\
\text { 4.Technology's sustainable competitive advantages and superiority as perceived by the user; } \\
\text { 5.The availability of a functioning prototype, the technology's degree of compatibility to other } \\
\text { necessary technologies ; } \\
\text { 6.Technology scope or future uses, technology uniqueness and superiority; } \\
\text { 7.The barriers to entry; } \\
\text { 8.The newness and the non-obviousness in the technology ; } \\
\text { 9.The technology's degree of dependability on other necessary technologies; } \\
\text { 10.The technology's identifiable and quantifiable technological risks and weaknesses; } \\
\text { 11.The technology development time to market, the stage of development of technology; } \\
\text { 12.The technical feasibility. }\end{array}$ \\
\hline $\begin{array}{l}\text { Commercializatio } \\
\mathrm{n} \text { - } \\
\text { related } \\
\text { determinants }\end{array}$ & $\begin{array}{l}\text { 1.The technology's identifiable current and immediate market needs; } \\
\text { 2.The absence of a dominant competitor in the technological field; } \\
\text { 3.The technology has a large definable potential market; } \\
\text { 4.The technology's market growth anticipation, the technology's expected market trend the time } \\
\text { for the technology to reach the target market penetration; } \\
\text { 5.Market accessibility for the technology (no dominant technology); } \\
\text { 6.The technology's competitive pricing; } \\
\text { 7.The technology has a reasonable probability of market success, the technology being first to } \\
\text { market (early mover advantage); } \\
\text { 8.The R\&D necessary for the technology to reach the product development stage; } \\
\text { 9.The technology's expected payoff period; } \\
\text { 10.The technology's expected positive return on investment within a specified period; } \\
\text { 11.The technology's financial risk. }\end{array}$ \\
\hline $\begin{array}{l}\text { Intellectual } \\
\text { property-related } \\
\text { determinants }\end{array}$ & $\begin{array}{l}\text { 1.The complete and clean technology's literature search; } \\
\text { 2.The completed patent search, and the patent search is clear and clean; } \\
\text { 3.The confidentiality of the technology; } \\
\text { 4.The technology has no prior claims; } \\
\text { 5.The strength of intellectual property; } \\
\text { 6.Exclusivity of intellectual property. }\end{array}$ \\
\hline Others & $\begin{array}{l}\text { 1.The trust and support of chief or leader in universities; } \\
\text { 2.The important role of university in the regional economic development; } \\
\text { 3.The unique function of integrating technology transfer into research; } \\
\text { 4.University's resources which are offered to technology transfer activities; } \\
\text { 5.The TTO needs to consider technology licensing and derivative new ventures; } \\
\text { 6.Offer professional knowledge or education for TTO employees, to evaluate the potential } \\
\text { market needs of technology; } \\
\text { 7.The management of research revenues, the connections between university and enterprise; } \\
\text { 8.The quality of college, the scale of TTO; } \\
\text { 9.Age of TTO; } \\
\text { 10.Ownership of academic intellectual property rights, the channel of technology transfer; } \\
\text { 11.Independence of university; } \\
\text { 12.External competitive environment. }\end{array}$ \\
\hline
\end{tabular}


Table 2. Summary of the cases - inventors

\begin{tabular}{|l|l|l|l|}
\hline Inventors & Technology types & Geographical distribution & $\begin{array}{l}\text { University attribute } \\
\text { ( national or private) }\end{array}$ \\
\hline $\mathrm{a}$ & Mechanical engineering & North region of Taiwan & Private \\
\hline $\mathrm{b}$ & Mechanical engineering & North region of Taiwan & National \\
\hline $\mathrm{c}$ & $\begin{array}{l}\text { Chemistry, chemical } \\
\text { engineering }\end{array}$ & Central region of Taiwan & National \\
\hline $\mathrm{d}$ & Materials engineering & Central region of Taiwan & Private \\
\hline $\mathrm{f}$ & Biomedical engineering & South region of Taiwan & Private \\
\hline
\end{tabular}

Table 3. Summary of the cases - technology transfer offices

\begin{tabular}{|l|l|l|l|}
\hline $\begin{array}{l}\text { TTO } \\
\text { administrators }\end{array}$ & Domain research fields & Geographical distribution & $\begin{array}{l}\text { University attribute } \\
\text { ( national or private) }\end{array}$ \\
\hline A & Mechanical engineering & North region of Taiwan & Private \\
\hline B & $\begin{array}{l}\text { Mechanical engineering } \\
\text { C }\end{array}$ & $\begin{array}{l}\text { North region of Taiwan } \\
\text { engineering }\end{array}$ & National \\
\hline D & Materials engineering & Central region of Taiwan & National \\
\hline E & $\begin{array}{l}\text { Electrical engineering, } \\
\text { mechanical engineering }\end{array}$ & South region of Taiwan & National \\
\hline F & Biomedical engineering & South region of Taiwan & Private \\
\hline
\end{tabular}

Table 4. The protection power for technology

\begin{tabular}{|l|l|l|}
\hline $\begin{array}{l}\text { Technology protection } \\
\text { mechanisms }\end{array}$ & Survey results & Main descriptions \\
\hline Patent & $\begin{array}{l}\text { b, c, d, } \\
\text { A, B, D, E }\end{array}$ & $\begin{array}{l}\text { Patent is crucial in technology protection, especially } \\
\text { for commercialised technology. }\end{array}$ \\
\hline Secret (know-how) & $\mathrm{a}, \mathrm{b}, \mathrm{E}, \mathrm{F}$, & $\begin{array}{l}\text { Secret and know-how is useful in technology } \\
\text { superiority or process complex industry. }\end{array}$ \\
\hline Leader time of technology & $\mathrm{a}$ & $\begin{array}{l}\text { Leader time is an important means for short } \\
\text { life-cycle technology. }\end{array}$ \\
\hline Early mover & $\mathrm{F}$ & $\begin{array}{l}\text { Early mover advantage is crucial for technology } \\
\text { protection, especially for biotechnology field. }\end{array}$ \\
\hline
\end{tabular}


Table 5. The important technology transfer determinants

\begin{tabular}{|l|l|l|}
\hline $\begin{array}{l}\text { Technology transfer } \\
\text { determinants }\end{array}$ & Survey results & Main descriptions \\
\hline Patent & a, b, d, B, D, E & $\begin{array}{l}\text { Patent has essential influence for the realization of } \\
\text { successful technology transfer. }\end{array}$ \\
\hline $\begin{array}{l}\text { Inventor } \\
\text { involvement and } \\
\text { cooperation as } \\
\text { a team player } \\
\text { (university-industry } \\
\text { cooperation) }\end{array}$ & a, b, c, f, B, F & $\begin{array}{l}\text { To possess a technique with patent is not the assurance for } \\
\text { technology transfer, inventor involvement is vital for } \\
\text { technology transfer. }\end{array}$ \\
\hline $\begin{array}{l}\text { Current market } \\
\text { needs }\end{array}$ & A, C & $\begin{array}{l}\text { They don't see patent as the crucial determinant for } \\
\text { technology transfer, both of them emphasise current market } \\
\text { needs of technology. }\end{array}$ \\
\hline Potential market & E & $\begin{array}{l}\text { The potential benefit or market needs of the technology is } \\
\text { the determinant of successful technology transfer. }\end{array}$ \\
\hline
\end{tabular}

Table 6. The efficacy of technology transfer office

\begin{tabular}{|c|c|c|}
\hline Perspective & & Attitude toward the efficacy of TTO \\
\hline \multirow[b]{2}{*}{ Inventor } & $\begin{array}{ll}\text { Positive } & \text { viewpoints } \\
\text { about TTO } & \end{array}$ & $\begin{array}{l}\text { Inventor } \mathrm{a}, \mathrm{b}, \mathrm{c}, \mathrm{f} \text { recognise the role of TTOs in } \\
\text { bringing inventions to practice. }\end{array}$ \\
\hline & $\begin{array}{ll}\text { Negative } & \text { viewpoints } \\
\text { about TTO } & \end{array}$ & $\begin{array}{l}\text { Inventor d argues university TTOs, especially in } \\
\text { Taiwan, can not prevent university inventions } \\
\text { from being infringed. Hence it is not easy for } \\
\text { universities to bring inventions to practice. }\end{array}$ \\
\hline Administrator of TTO & $\begin{array}{ll}\begin{array}{l}\text { Positive } \\
\text { about TTO }\end{array} & \text { viewpoints } \\
\end{array}$ & $\begin{array}{l}\text { Most of the TTO administrators approve TTO's } \\
\text { contribution for technology transfer. }\end{array}$ \\
\hline
\end{tabular}

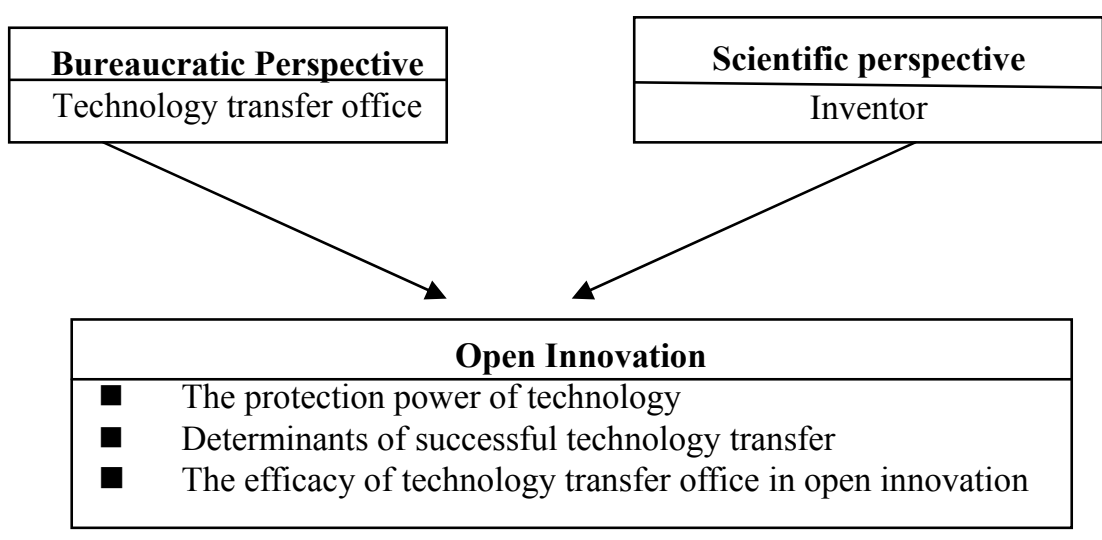

Figure 1. Research framework- technology transfer in open innovation 